\title{
UREA AS THE BASIC COMPONENT IN PYRIDINE-FREE KARL FISCHER REAGENT
}

\author{
M. Bos \\ Department of Chemical Technology, Technical University Twente, P.O. Box 217, 7500 AE Enschede, \\ The Netherlands
}

(Received 6 December 1983. Accepted 18 January 1984)

\begin{abstract}
Summary-A solution of urea, sulphur dioxide and sodium salicylate in methanol is proposed as the solvent in the Karl Fischer titration, with a separate iodine solution as titrant. Comparison of the performance of this solvent with that of some commercial reagents shows that it is has distinct advantages for use with amine samples.
\end{abstract}

Since the elucidation of the reaction mechanism of the Karl Fischer titration by Verhoef and Barendrecht, ${ }^{1,2}$ a number of compounds have been proposed to replace the pyridine in the classical reagent, viz. sodium acetate, ${ }^{3}$ diethanolamine ${ }^{4}$ and imidazole. ${ }^{5}$ These components serve, as the pyridine did, to buffer the titration medium at a $\mathrm{pH}$-value that ensures a convenient overall titration rate and a stable endpoint. Other criteria that determine the usefulness of the reagents are the long-term stability of the solution and the number of classes of compound for which the water determination can be done without problems.

The goal of the investigation described here was the preparation of a new reagent that-just like the original pyridine-containing reagent - would have its buffering action in a more acidic range than that of the reagents mentioned above.

\section{EXPERIMENTAL}

\section{Reagents}

The following substances were used as received: urea (puriss. p.a.), triethanolamine (puriss. p.a.) and imidazole (purum) from Fluka, sodium salicylate (zur Analyse) from Merck, triethylamine (puriss.) from Koch-Light, salicyclic acid from ACF, sulphur dioxide from Matheson, and the sodium salt of benzenesulphinic acid from Janssen. The methanol used to prepare the Karl Fischer solvents was reagent grade from Baker, and dried with $3 \mathrm{~A}$ molecular sieve (Union Carbide) for $24 \mathrm{hr}$ before use. The lithium chloride (Merck, Suprapur) was dried for $24 \mathrm{hr}$ at $150^{\circ}$.

The commercial Karl Fischer solvents used were Karl Fischer Lösung A (Merck, Pyridin Schwefeldioxid Lösung), Karl Fischer Lösungsmittel Pyridinfrei (Merck) and Hydranal solvent (Riedel-de Haën).

\section{Apparatus}

The titrations were done with Radiometer Karl Fischer titration equipment consisting of the Karl Fischer titration assembly TT-A1-KF, titrator TTTllb and $\mathrm{mV} / \mathrm{pH}$-meter PHM28. The $\mathrm{pH}$ of the titration medium was measured with a Knick pH-meter, type PH60, and an Ingold combined glass/reference electrode, type 405 , of which the reference electrode compartment was filled with a saturated solution of lithium chloride in methanol. The electrode was calibrated with methanolic solutions of salicylic acid and sodium salicylate as described by Bos and Lengton. ${ }^{6}$

\section{Procedure}

The titration procedure is based on the separate titrant/solvent-reagent system and was performed as follows. The titration vessel was filled with $20 \mathrm{ml}$ of the reagent under study $\left(\mathrm{SO}_{2} /\right.$ base/methanol) and pretitrated with the iodine/methanol titrant to a preset end-point $(300 \mathrm{mV})$ with

Table 1. The amount of water that can be titrated in $20 \mathrm{ml}$ of reagent, and the resulting $\mathrm{pH}$-change

\begin{tabular}{|c|c|c|}
\hline Reagent & pH-change & $\begin{array}{l}\text { Water capacity, } \\
m g\end{array}$ \\
\hline Karl Fischer (Verhoef) & $5.0-2.1$ & 55 \\
\hline $\begin{array}{l}\text { Hydranal (Riedel-de } \\
\text { Haën) }\end{array}$ & $5.6-2.6$ & 130 \\
\hline $\begin{array}{l}\text { Karl Fischer Lösung } \\
\text { A (Merck) }\end{array}$ & $4.2-1.2$ & 250 \\
\hline $\begin{array}{l}1 \mathrm{M} \text { Imidazole/ } \\
0.5 \mathrm{M} \mathrm{SO}_{2} / \mathrm{MeOH}\end{array}$ & $6.7-4.7$ & 100 \\
\hline $\begin{array}{l}1.5 M \text { Urea/1.5M SO } / \\
0.5 M \text { Na salicylate } / \mathrm{MeOH}\end{array}$ & $1.6-0.9$ & 140 \\
\hline $\begin{array}{l}0.5 M \text { Urea/0.5M Na } \\
\text { benzenesulphinic acid/ } \\
1 M \mathrm{SO}_{2} / \mathrm{MeOH}\end{array}$ & $2.1-0.9$ & 90 \\
\hline 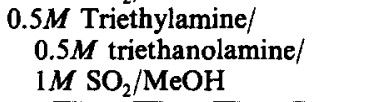 & $9.0-7.0$ & 110 \\
\hline
\end{tabular}


Table 2. Long-term stability of Karl Fischer solvent with composition $1.5 \mathrm{M}$ $\begin{array}{lll}\text { urea/ } / 0.5 M & \mathrm{Na} \text { salicylate/ } / .5 M & \mathrm{SO}_{2} /\end{array}$ $\mathrm{MeOH}$

\begin{tabular}{cc}
\hline \multicolumn{2}{c}{ MeOH } \\
$\begin{array}{c}\text { Storage time, } \\
\text { weeks }\end{array}$ & $\begin{array}{c}\text { Water content of } \\
\text { 20 ml of solvent, } \\
\text { mg }\end{array}$ \\
\hline- & 4.63 \\
1 & 4.64 \\
2 & 4.63 \\
3 & 4.65 \\
4 & 4.70 \\
5 & 4.82 \\
6 & 4.91 \\
7 & 5.03 \\
8 & 5.25 \\
9 & 5.39 \\
\hline
\end{tabular}

Table 3. Titration speed and $\mathrm{pH}$-change for the titration of $100 \mathrm{mg}$ of water in $20 \mathrm{ml}$ of urea/Na salicylate $/ \mathrm{SO}_{2} /$ methanol reagent

\begin{tabular}{ccccc}
\hline $\begin{array}{c}\text { [Urea], } \\
\mathbf{M}\end{array}$ & $\begin{array}{c}\text { [Salicylate], } \\
\mathbf{M}\end{array}$ & $\begin{array}{c}\left.\mathrm{SO}_{2}\right], \\
\mathbf{M}\end{array}$ & $\begin{array}{c}\text { pH-change } \\
\text { min }\end{array}$ & $\begin{array}{c}\text { Titration } \\
\text { time, } \\
\text { min }\end{array}$ \\
\hline 1.0 & 0.5 & 1.0 & $1.8-0.9$ & 10.0 \\
1.2 & 0.5 & 1.0 & $1.7-1.0$ & 8.5 \\
1.4 & 0.5 & 1.0 & $1.7-1.0$ & 7.0 \\
1.6 & 0.5 & 1.0 & $1.8-1.0$ & 6.0 \\
1.8 & 0.5 & 1.0 & $1.9-1.0$ & 5.5 \\
2.0 & 0.5 & 1.0 & $1.9-1.0$ & 5.0 \\
1.4 & 0.5 & 1.5 & $1.6-1.3$ & 7.5 \\
1.6 & 0.5 & 1.75 & $1.6-1.3$ & 5.0 \\
1.8 & 0.5 & 2.0 & $1.7-1.3$ & 4.0 \\
2.0 & 0.5 & 2.25 & $1.7-1.3$ & 3.8 \\
\hline
\end{tabular}

Table 4. Comparison of $1.5 \mathrm{M}$ urca/0.5 $\mathrm{M} \mathrm{Na}$ salicylatc/1.5M $\mathrm{SO}_{2} / \mathrm{MeOH}$ with commercial Karl Fischer solvents

\begin{tabular}{|c|c|c|c|}
\hline \multirow[b]{2}{*}{ Sample } & \multicolumn{3}{|c|}{$\mathrm{H}_{2} \mathrm{O}$ found, $\%$ remarks } \\
\hline & Hydranal & $\begin{array}{l}\text { KF Lösungsmittel } \\
\text { pyridinfrei (Merck) }\end{array}$ & $\begin{array}{l}\text { Urea/Na salicylate/ } \\
\mathrm{SO}_{2} / \mathrm{MeOH}\end{array}$ \\
\hline $\begin{array}{l}\mathrm{Na} \text { tartrate } 2 \mathrm{H}_{2} \mathrm{O} \\
2 \mathrm{aq} .\end{array}$ & \begin{tabular}{l}
\multicolumn{1}{c}{15.65} \\
precipitate \\
when $>250 \mathrm{mg}$ \\
sample added
\end{tabular} & 15.64 & 15.64 \\
\hline acetone & $\begin{array}{l}\text { no results, owing } \\
\text { to ketal } \\
\text { formation }\end{array}$ & $\begin{array}{l}\text { no results, owing } \\
\text { to ketal } \\
\text { formation }\end{array}$ & $\begin{array}{l}\text { no results, owing } \\
\text { to ketal } \\
\text { formation }\end{array}$ \\
\hline methyl acetate & 0.0597 & 0.060 & 0.0585 \\
\hline ethanol & 0.0718 & 0.0720 & 0.0719 \\
\hline acetic acid & $\begin{array}{l}\quad 0.0593 \\
\text { dragging end-point } \\
\text { with increasing } \\
\text { number of samples }\end{array}$ & $\begin{array}{l}\quad 0.0643 \\
\text { dragging end-point } \\
\text { with increasing } \\
\text { number of samples }\end{array}$ & $\begin{array}{l}\quad 0.0665 \\
\text { dragging end-point } \\
\text { with increasing } \\
\text { number of samples }\end{array}$ \\
\hline chloroform & $\begin{array}{l}\quad 0.00989 \\
\text { large variations } \\
\text { in results }\end{array}$ & $\begin{array}{c}0.0100 \\
\text { no problems }\end{array}$ & $\begin{array}{c}0.0107 \\
\text { no problems }\end{array}$ \\
\hline diethyl ether & $\begin{array}{c}0.0424 \\
\text { accurate results } \\
\text { after } 3 \text { samples }\end{array}$ & $\begin{array}{l}\quad 0.0441 \\
\text { first determination } \\
\text { inaccurate }\end{array}$ & $\begin{array}{l}\quad 0.0474 \\
\text { first determination } \\
\text { inaccurate }\end{array}$ \\
\hline dimethylformamide & $\begin{array}{l}\quad 0.0343 \\
\text { solvents turns } \\
\text { dark }\end{array}$ & $\begin{array}{l}\quad 0.0359 \\
\text { solvent turns } \\
\text { dark }\end{array}$ & $\begin{array}{l}0.0346 \\
\text { slight darkening }\end{array}$ \\
\hline petroleum ether & $\begin{array}{l}\text { no results, owing } \\
\text { to precipitation }\end{array}$ & $\begin{array}{l}\text { no results, owing } \\
\text { to precipitation }\end{array}$ & $\begin{array}{l}\quad 0.00903 \\
\text { precipitation only } \\
\text { after } 4 \mathrm{~g} \text { of } \\
\text { sample added }\end{array}$ \\
\hline n-butylamine & $\begin{array}{l}\text { no results } \\
\text { strongly } \\
\text { dragging end-point }\end{array}$ & $\begin{array}{l}2.30 \\
\text { dragging end-point }\end{array}$ & $\begin{array}{l}2.29 \\
\text { stable end-point }\end{array}$ \\
\hline n-dibutylamine & $\begin{array}{l}\quad 0.619 \\
\text { inaccurate, } \\
\text { dragging end-point }\end{array}$ & $\begin{array}{l}\quad 0.462 \\
\text { first determination } \\
\text { inaccurate, } \\
\text { somewhat dragging } \\
\text { end-point }\end{array}$ & $\begin{array}{c}0.451 \\
\text { no problems }\end{array}$ \\
\hline tributylamine & $\begin{array}{l}\quad 0.166 \\
\text { inaccurate, } \\
\text { dragging end-point }\end{array}$ & $\begin{array}{l}0.115 \\
\text { dragging end-point }\end{array}$ & $\begin{array}{c}0.105 \\
\text { no problems }\end{array}$ \\
\hline quinoline & 0.160 & 0.151 & 0.148 \\
\hline benzylamine & $\begin{array}{l}1.30 \\
\text { inaccurate, } \\
\text { dragging end-point }\end{array}$ & $\begin{array}{c}1.20 \\
\text { no problems }\end{array}$ & $\begin{array}{c}1.21 \\
\text { no problems }\end{array}$ \\
\hline
\end{tabular}


the bipotentiometric detection system, operated with a fixed current in the range $2-3 \mu \mathrm{A}$. The value of $300 \mathrm{mV}$ should persist for at least $20 \mathrm{sec}$. After this pretitration the watercontaining sample was introduced into the titration vessel and the titrator was started again.

The short-term stability of the reagent was checked by measuring the iodine titrant consumption after the stop criterion of the titration was met, by continuing the titration in the "no stop mode". The iodine/methanol reagent was standardized against weighed samples of pure water. The long-term stability of the reagent was checked by periodically measuring the amount of iodine titrant consumed in the pretitrations.

\section{RESULTS}

Table 1 shows the amount of water that can be titrated in $20 \mathrm{ml}$ of solvents of various compositions, together with the change in $\mathrm{pH}$ that accompanies the process.

A solvent with the composition $1 M$ urea/1M $\mathrm{SO}_{2} /$ methanol gave inaccurate results because the reaction proceeded very slowly, and was not studied any further.

As can be seen, the urea/sodium salicylate/ $\mathrm{SO}_{2} /$ methanol mixture is the most acidic of the reagents tested and the only one that shows overlap in $\mathrm{pH}$-range on the acidic side with the classical pyridine $/ \mathrm{SO}_{2} /$ methanol reagent as manufactured by Merck. The amount of water that can be titrated in $20 \mathrm{ml}$ of this reagent compares favourably with that for the commercial products not containing pyridine.

The urea/sodium salicylate $/ \mathrm{SO}_{2} /$ methanol mixture was investigated somewhat further with regard to its stability on storage (Table 2) and with regard to the influence of the concentrations of its constituents on the speed of the titration (Table 3).

Table 2 shows that the stability on storage is rather good. No significant increase in the water content of the reagent was observed during the first 4 weeks of storage at room temperature, and only a minor increase after that period.
From Table 3 it can be seen that an increase in the concentrations of urea and sulphur dioxide considerably speeds up the titration of $100 \mathrm{mg}$ of water. At concentrations of urea and sulphur dioxide above $1.5 M$ the gain in titration speed levels off. This composition seemed a good compromise between reagent cost and titration speed and was compared with two commercial products in the consecutive titration of a number of actual samples of different chemical classes (Table 4). All titrations were performed with $20 \mathrm{ml}$ of reagent as solvent. The sample size varied between 1 and $4 \mathrm{~g}$, depending on the water content. For the entries marked "no problems" in Table 4 , the reproducibility was better than $\pm 1 \%$.

In general the results obtained with the ureacontaining reagent are comparable with those obtained with the commercial reagents. However, for the amine samples there is a significant difference; these can only be titrated successfully in the ureacontaining reagent. It is likely that this is due to the more acidic nature of this reagent. The effect of varying the sodium salicylate concentration was not examined, since the $0.5 M$ concentration initially used seemed suitable enough.

Acknowledgements - The author wishes to acknowledge the co-operation and financial support of J. T. Baker Chemicals B.V. in this investigation and expresses his thanks to $R$. Groot Rouwen and W. Lengton for performing the experimental work.

\section{REFERENCWS}

1. J. C. Verhoef and E. Barendrecht, J. Electroanal. Chem., 1976, 71, 305.

2. Idem, ibid., 1977, 75, 705.

3. J. C. Verhoef, Mechanism and Reaction Rate of the Karl Fischer Titration Reaction, Dissertation, University of Amsterdam, 1977.

4. E. Scholtz, Z. Anal. Chem., 1981, 309, 30.

5. Idem, ibid., 1982, 312, 462.

6. M. Bos and W. Lengton, Anal. Chim. Acta, 1973, 76, 149. 